Open Access

\title{
Central defect type partial $A C L$ injury model on goat knees: the effect of infrapatellar fat pad excision
}

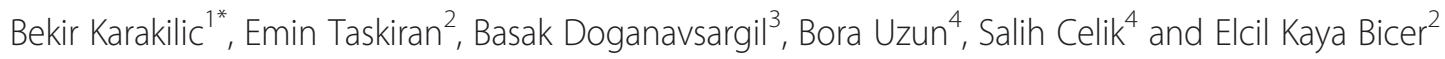

\begin{abstract}
Background: The mid-substance central defect injury has been used to investigate the primary healing capacity of the anterior cruciate ligament (ACL) in a goat model. The sagittal plane stability on this model has not been confirmed, and possible effects of fat pad excision on healing have not been evaluated. We hypothesize that excising the fat pad tissue results in poorer ligament healing as assessed histologically and decreased tensile strength of the healing ligament. We further hypothesize that the creation of a central defect does not affect sagittal plane knee stability.

Methods: A mid-substance central defect was created with a 4-mm arthroscopic punch in the ACLs of right knees of all the subjects through a medial mini-arthrotomy. Goats were assigned to groups based on whether the fat pad was preserved (group 1, $n=5$ ) or excised completely (group $2, n=5$ ). The left knees served as controls in each goat. Histopathology of the defect area along with measurement of type I collagen in one goat from each group were performed at 10th week postoperatively. The remaining knees were evaluated biomechanically at the 12th week, by measuring anterior tibial translation (ATT) of the knee joints at $90^{\circ}$ of flexion and testing tensile properties (ultimate tensile load (UTL), ultimate elongation (UE), stiffness (S), failure mode (FM)) of the femur-ACL-tibia complex.
\end{abstract}

Results and discussion: Histopathology analysis revealed that the central defect area was fully filled macroscopically and microscopically. However, myxoid degeneration and fibrosis were observed in group 2 and increased collagen type I content was noted in group 2. There were no significant differences within and between groups in terms of ATT values ( $p=0.715$ and $p=0.149$, respectively). There were no significance between or within groups in terms of ultimate tensile load and ultimate elongation; however, group 2 demonstrated greater stiffness than group 1 that was correlated with the fibrotic changes detected microscopically $(p=0.043)$.

Conclusions: The central defect type injury model was confirmed to be biomechanically stable in a goat model. Resection of the fat pad was noted to negatively affect defect healing and increase ligament stiffness in the central defect injury model.

Keywords: Partial ACL injury model, Primary healing, Infrapatellar fat pad

\footnotetext{
*Correspondence: isha_Shinai@Yahoo.Com

'Orthopaedics and Traumatology Clinic, Bayburt State Hospital, Bayburt,

Turkey

Full list of author information is available at the end of the article
}

\section{Biomed Central}

(c) 2015 Karakilic et al. Open Access This article is distributed under the terms of the Creative Commons Attribution 4.0 International License (http://creativecommons.org/licenses/by/4.0/), which permits unrestricted use, distribution, and reproduction in any medium, provided you give appropriate credit to the original author(s) and the source, provide a link to the Creative Commons license, and indicate if changes were made. The Creative Commons Public Domain Dedication waiver (http://creativecommons.org/publicdomain/zero/1.0/) applies to the data made available in this article, unless otherwise stated. 


\section{Introduction}

The anterior cruciate ligament (ACL) has an important role in knee joint stability. Injuries in active individuals can jeopardize future athletic function and lead to degenerative arthritis. These concerns have led to many the studies on surgical reconstruction of the ACL in recent years, but there is still no gold standard treatment proven to reliably restore function and prevent arthritis. The primary healing capacity of ACL tissue is limited compared to other ligaments such as the medial collateral ligament (MCL) due to differences in vascularity, biological environment, and mechanical processes [1-5]. These influences on these factors and potential interventions can be effectively studied with animal injury models [6-16]. The central defect type partial ACL injury model described by Murray et al is thought to be a mechanically stable model, which enables concentration on healing and repair processes $[6,10,11]$. The goat knee was selected as suitable animal model due to its anatomical and mechanical similarities to the human knee joint [17-19] and that has been utilized in multiple prior studies [20-33].

The infrapatellar fat pad has been shown to have an important role in ACL circulation [34-36]. However, in previous studies using the central defect model, the injury was created without regard to protection of the fat pad tissue. Further, although the model has been assumed to be mechanically stably in the sagittal plane, this stability has not been confirmed to mechanical testing.

In this study we aimed to investigate the primary healing capacity of the ACL using central defect type partial injury model and evaluate the effect of fat pad excision on ligament histology and strength. We also aim to confirm the sagittal plan stability of the central defect model. We hypothesize that excising fat pad tissue results in poorer ligament healing as assessed histologically and decreased tensile strength of the healing ligament. We further hypothesize that the creation of a central defect does not affect sagittal plane knee stability.

\section{Methods}

\section{Study groups}

Ten adolescent female Anatolian Black Goats aged between 7 and 11 months were included in the study. Approval and permission from Ege University Animal Care and Use Ethic Committee was obtained for the study. All animals were anesthetized with a ketamine-xylazine combination by a specialist veterinary physician. Five animals were assigned to each of two groups. In group 1 , a central defect was created in the ACL of the right knee joints of the animal without any harm to the fat pad tissue. In group 2, the same ACL injury model was performed after complete excision of the infrapatellar fat

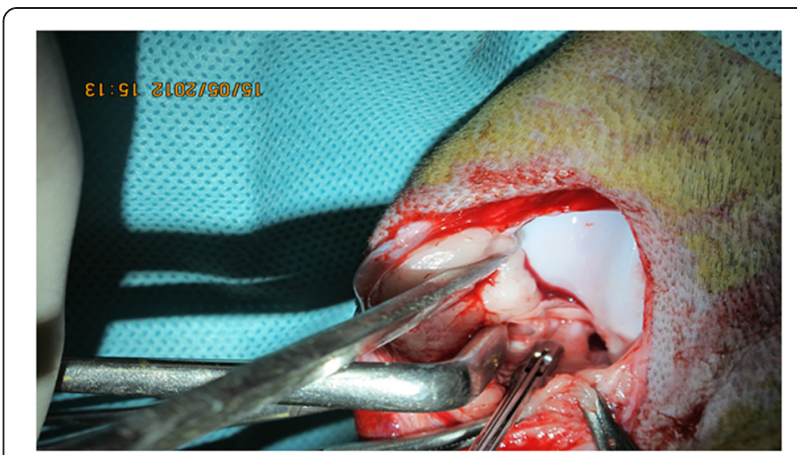

Fig. 1 Creating central defect in $\mathrm{ACL}$

pad tissue. Left knee joints were left as controls without any intervention.

\section{Surgical technique}

All knee joints of the animals were prepared under sterile conditions. To decrease intraoperative bleeding and gain clear exposure, subcutaneous jetocaine was injected before the skin incision. A medial parapatellar skin incision approximately $5 \mathrm{~cm}$ long was created, and a medial mini-arthrotomy was performed to access the joint in both groups. In group 1, the infrapatellar fat pad and synovial folds were protected and gently retracted to visualize the ACL. A central defect was then created by excising full thickness ligament tissue with a 4-mm arthroscopic punch (Figs. 1 and 2). In group 2, complete excision of the infrapatellar fat pad tissue was performed before creating the same central defect type injury in ACL (Fig. 3). After irrigating the knee joint, the arthrotomy and skin incision were closed in the same manner in both groups.

\section{Postoperative care}

All animals were restricted to cage activity for 6 weeks after surgery. Analgesia (Metamizole, $20 \mathrm{mg} / \mathrm{kg}$ twice daily) and

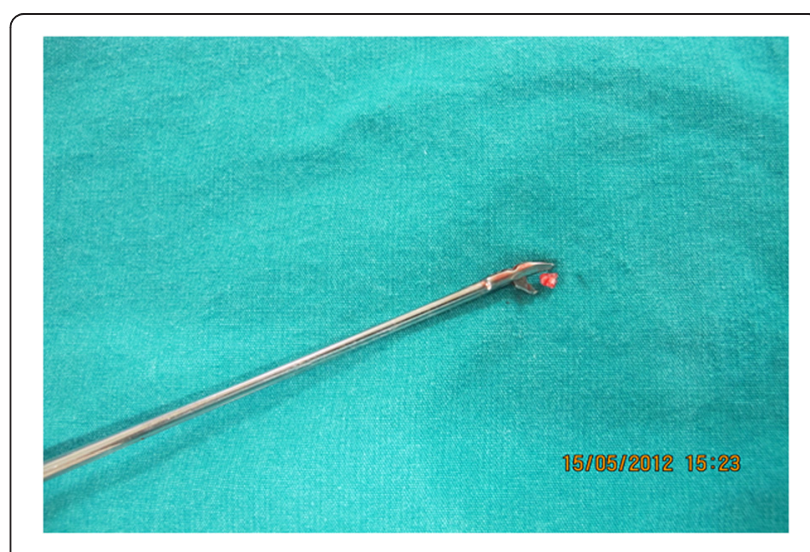

Fig. 2 Excised full thicknees tissue from ACL for central defect 


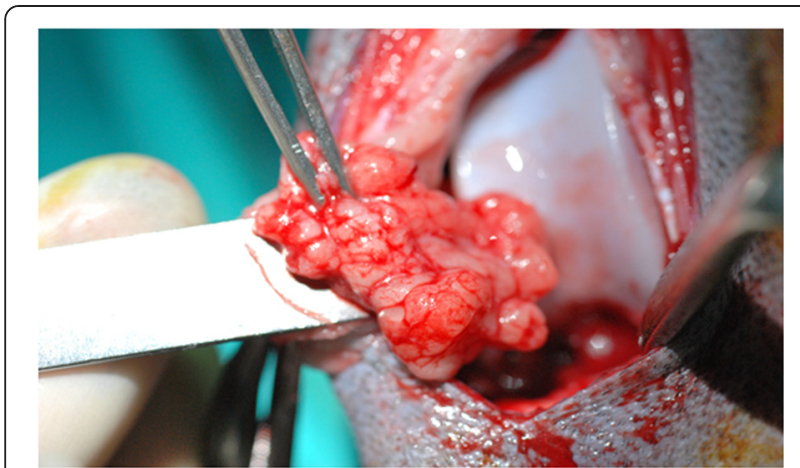

Fig. 3 Fat pad excision

antibiotic prophylaxis (penicillin, $20.000 \mathrm{IU} / \mathrm{Kg}$ twice daily) were given during the early postoperative period (48 h). The surgical wounds were closed completely in 10 days. After 6 weeks, the animals were allowed daily activities out of the cages.

Two animals (one from each group) that were chosen at random for histopathology were sacrificed with overdose of pentobarbital at week 10, and the remaining animals were sacrificed at week 12 for mechanical testing. The hind limbs were amputated through the midshaft of the femur and tibia and kept at $-20{ }^{\circ} \mathrm{C}$ until mechanical testing.
Histopathological and immunohistochemical evaluation Histopathology was performed on the operated and control knees of one randomly selected animal from each group sacrificed during week 10. Macroscopic evaluation was performed to detect the fill of the defect as well as to evaluate for any cartilage lesions. Histological analysis was performed to compare the samples for cellular and vascular responses. Immunohistochemistry was performed to compare the amount of type I collagen at the injury sites.

The samples from the sacrificed animals were stored at $4{ }^{\circ} \mathrm{C}$. The knee joints were carefully dissected. The ACL injury area in the experimental knees and the corresponding area in the control knees were resected and fixed in $10 \%$ formaldehyde solutions for $24 \mathrm{~h}$. Four to five micrometric paraffin blocks were prepared and stained with hematoxylin eosin. Immunohistochemistry assessment for type I collagen was performed in frozen sections taken by cryomicrotome. After an antigenproducing stage with baking (EDTA pH, $85 \mathrm{~min} / 850 \mathrm{~W}$ microwave), the samples were stained with monoclonal antibody for collagen-1 (collagen 1 antibody; 5D8-G9/ Coll-NOVUS) and kept at $4{ }^{\circ} \mathrm{C}$ for $24 \mathrm{~h}$. Final labeling was performed with the streptoavidin-biotin method using dab chromogen. Kidney tissue was used for positive comparison.

\begin{tabular}{|c|c|c|c|c|}
\hline & Thickness & Width & Gauge Length & \\
\hline Units & $\mathrm{mm}$ & $\mathrm{mm}$ & $\mathrm{mm}$ & \\
\hline $1-1$ & 1.0000 & 1.0000 & 100.0000 & \\
\hline Name & Max Force & Max Disp & Min Force & Min Disp \\
\hline Units & $\mathbf{N}$ & $\mathrm{mm}$ & $\mathbf{N}$ & $\mathrm{mm}$ \\
\hline Cycle \#1 & 67.5000 & 4.37600 & -67.031 & -6.7120 \\
\hline Cycle \#2 & 67.8125 & 4.43700 & -67.188 & -6.8090 \\
\hline Cycle \#3 & 67.1875 & 4.44300 & -67.656 & -6.8680 \\
\hline Cycle \#4 & 67.0313 & 4.42900 & -66.875 & -6.8750 \\
\hline Cycle \#5 & 67.9688 & 4.44100 & -67.344 & -6.9380 \\
\hline Cycle \#6 & 66.8750 & 4.43900 & -67.500 & -6.9680 \\
\hline Cycle \#7 & 66.8750 & 4.43100 & -66.875 & -6.9720 \\
\hline Cycle \#8 & 67.0313 & 4.43100 & -66.719 & -6.9400 \\
\hline Cycle \#9 & 67.0313 & 4.44200 & -67.656 & -7.0050 \\
\hline Crcle \#10 & 67.3438 & 4.44200 & -66.250 & -6.9890 \\
\hline
\end{tabular}

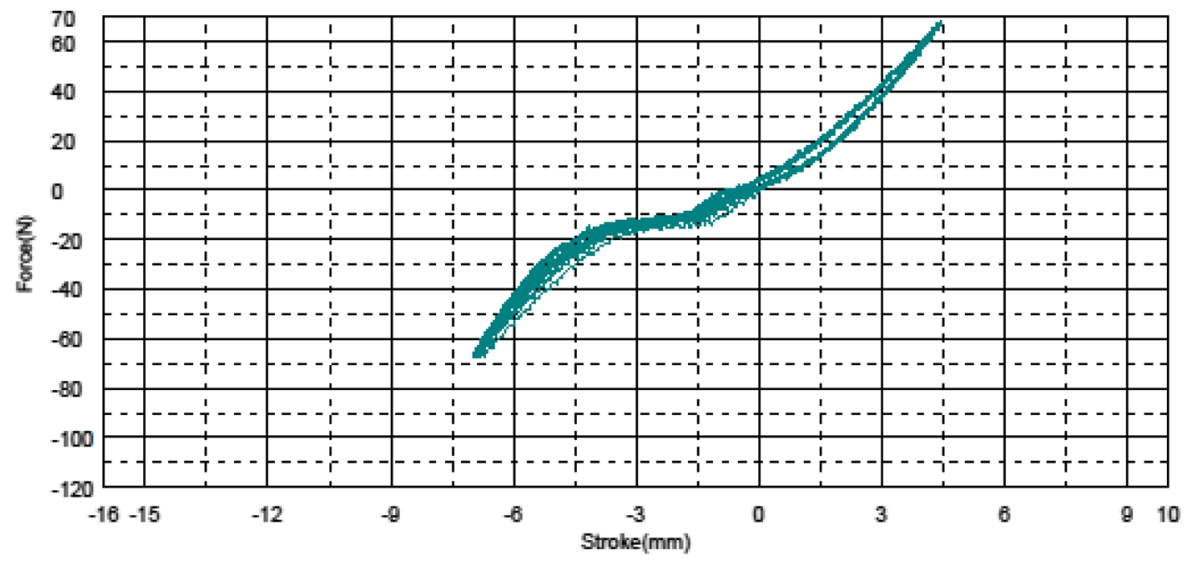

Fig. 4 Anterior tibial translation test data of a sample 


Shape: Plate
\begin{tabular}{|c|c|c|c|c|c|}
\hline & Thickness & Width & Gauge Length \\
\hline Units & $\mathrm{mm}$ & $\mathrm{mm}$ & $\mathrm{mm}$ \\
\hline $1-1$ & 1.0000 & 1.0000 & 100.0000 & \\
\hline Name & Max Force & Max Disp & Break Force & Break Disp & YP Force \\
\hline Parameter & & & & & $0.1 \% / \mathrm{FS}$ \\
\hline Units & $\mathrm{N}$ & $\mathrm{mm}$ & $\mathrm{N}$ & $\mathrm{mm}$ & $\mathrm{N}$ \\
\hline $1-1$ & 373.504 & 8.24600 & 250.781 & 9.09600 & 205.625 \\
\hline
\end{tabular}

\begin{tabular}{|c|c|}
\hline Name & YP Disp \\
\hline Parameter & $0.1 \% 6 / F S$ \\
\hline Units & mm \\
\hline $1-1$ & 5.47900 \\
\hline
\end{tabular}

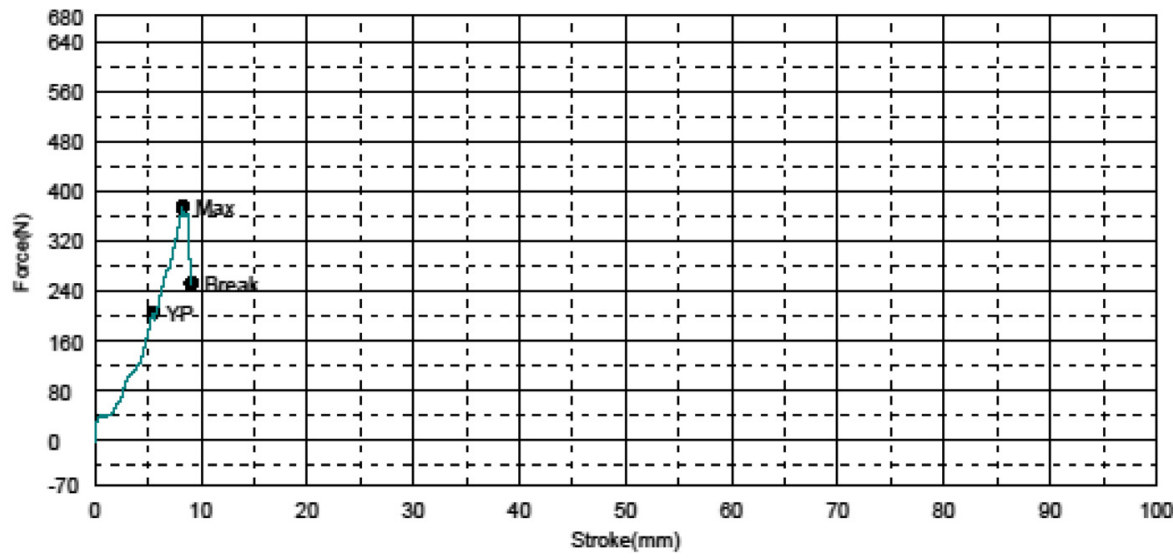

Fig. 5 Tensile load to failure data of a sample

\section{Mechanical testing}

We measured the structural properties of the ligament as well as sagittal joint laxity (anterior tibial translation) to which the ACL is the primary contributor. A Shimadzu AG $10 \mathrm{~K}$ mechanical testing machine was used. In order to attach the joint samples to the machine, a custom device was manufactured as in the previous biomechanical studies [19, 37]. The knee joints of four animals in each group were tested. The previously amputated and frozen limb samples were allowed to thaw at room temperature

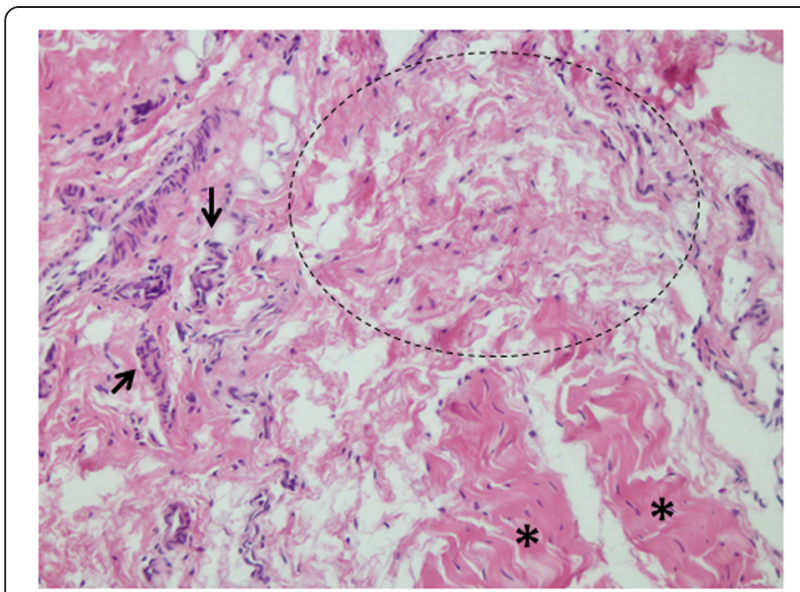

Fig. 6 Microscopic section showing the filled defect area surrounded by vascular proliferation (arrows) and normal ligament tissue (stars)
$12 \mathrm{~h}$ before testing. After complete thawing, the soft tissues $5 \mathrm{~cm}$ proximal and distal to the joint line were dissected carefully preserving surrounding the soft tissues and joint capsule. The bones were embedded in cylindrical molds with bone cement. To measure anterior tibial translation, the cylindrical molds holding the knee samples were put into the cylindrical parts of the manufactured device and the whole system was located and fixed to the test machine orienting the tibia vertical and the knee flexed to $90^{\circ}$. The joint was cyclically loaded up to 67

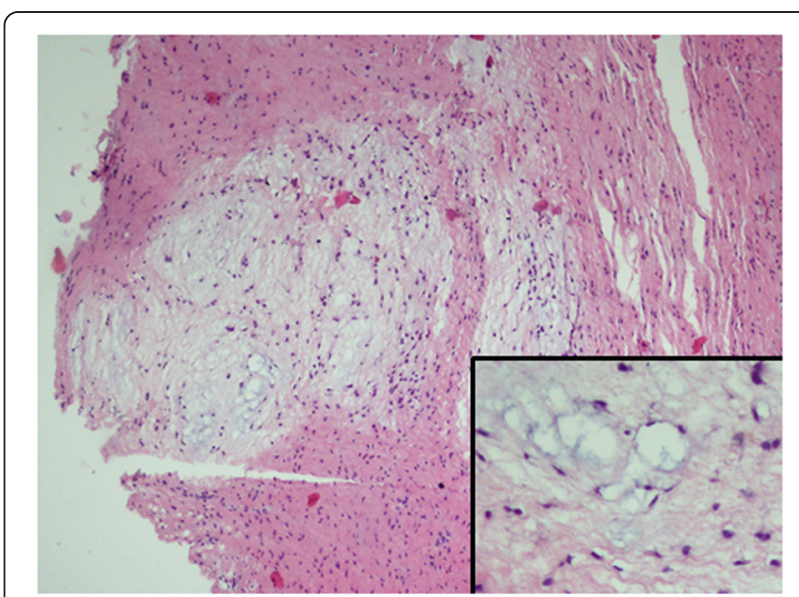

Fig. 7 Microscopic section showing the defect area of fat-pad excised sample: having edema and myxoid degeneration fields 
Table 1 Vascular structures per micro observation site

\begin{tabular}{ll}
\hline Sample & Vascular count \\
\hline A3-Experiment knee & 25 \\
A3-Control & 11 \\
B1-Experiment knee & 46 \\
B1-Control & 25 \\
\hline
\end{tabular}

Newtons (N) anteriorly and posteriorly at a rate of $20 \mathrm{~mm} / \mathrm{min}$ ( $\mathrm{min}$ ) in order to simulate the in situ load born by the ACL in goats according to prior work [38]. The mean anterior displacement of 10 cycles of loading was recorded as the mean anterior tibial translation value of the specimens (Fig. 4). After finishing the anterior tibial translation (ATT) test, the specimens were taken out of the system. The remaining soft tissues including the capsule, menisci, collateral ligaments, and posterior cruciate ligament (PCL) were excised to obtain the femurACL-tibia complex. The femur-ACL-tibia complex were located and fixed to the test machine again for tensile tests. After pre-tensioning ( $5 \mathrm{~N}$ for $10 \mathrm{~min}$ ) and preconditioning (10 cycles of load up to $20 \mathrm{~N}$ ) stages, each specimen was tested to failure at $20 \mathrm{~mm} / \mathrm{min}$. Ultimate tensile load (Newton), ultimate elongation ( $\mathrm{mm})$, stiffness (N/meter), and failure locations were recorded (Fig. 5).

\section{Statistical analysis}

Statistical analysis was performed utilizing SPSSv18 package program. Mann-Whitney $U$ and Wilcoxon's signed rank test were used for inter- and intragroup analysis, respectively. The level of statistical significance was set at $p<0.05$.

\section{Results}

Histopathology and immunohistochemistry findings

Macroscopic evaluations of all knees revealed full filling of injury site (Fig. 6). No cartilage lesion was detected among these samples. Microscopic evaluations showed more fibroblastic cells in the injured ACLs compared to their controls. No inflammatory cells were observed (Table 1). More vascular structures were detected surrounding the defect area in group 2 (fad pad excised). Histological assessment of this group also showed edematous changes and myxoid degeneration in the ligament

Table 2 Collagen type 1 stained fiber count

\begin{tabular}{ll}
\hline Sample & Fiber count \\
\hline A3-Experiment knee & 69 \\
A3-Control & 68 \\
B1-Experiment knee & 88 \\
B1-Control & 42 \\
\hline
\end{tabular}

Table 3 Group A mean ATT values ( $\mathrm{mm}$ )

\begin{tabular}{lll}
\hline Subject & Experiment knee & Control knee \\
\hline A-1 & 6.4117 & 0.8788 \\
A-2 & 4.1572 & 2.8145 \\
A-4 & 3.1554 & 5.907 \\
A-5 & 3.3138 & 4.4311 \\
\hline A-3 undergone pathologic assessment
\end{tabular}

injury site (Fig. 7). In contrast, normal histological healing of the ACL injury site was observed in group 1 (fat pad protected). More type 1 collagen stained fibers were detected in the injury site of the fat pad excised sample (Table 2).

\section{Biomechanical findings \\ ATT findings}

No significant differences (group 1, $\mathrm{p}=0.715$; group $2, \mathrm{p}=0.715$ ) (Tables 3 and 4) were found in sagittal joint laxity between the injured and control knee in either group. Fat pad excision had no effect on sagittal joint laxity $(\mathrm{p}=0.149)$

\section{Tensile loading findings}

Injured knee samples did not show any significant difference from their controls in tensile loadings in terms of ultimate tensile load (Tables 5 and 6). Stiffness values of the injured knees with fat pad excision were significantly higher than the fat pad preserved samples $(p=0.043)$. Tibial avulsion was the most common mode of failure among the samples in the tensile load analyses ( 9 of 16 knees)

\section{Discussion}

In our study, we aimed to investigate the primary healing capacity of the ACL tissue using the central defect type ACL injury model that was popularized by Murray et al. They performed and standardized this model for their studies for investigation of the primary healing and repair capacity of the ACL as compared to other ligaments and evaluation of healing enhancement methods with tissue engineering products $[6,10,11]$. They mainly concentrated on the histological healing process and emphasized that the model has healing capacity and that can be improved with tissue engineering products. In their studies, the biomechanical tests were only tensile

Table 4 Group B mean ATT values (mm)

\begin{tabular}{lll}
\hline Subject & Experiment knee & Control knee \\
\hline B-2 & 2.613 & 4.4991 \\
B-3 & 3.4019 & 2.1616 \\
B-4 & 3.1074 & 1.9328 \\
B-5 & 3.2669 & 2.9025 \\
\hline
\end{tabular}

$B-1$ undergone pathologic assessment 
Table $\mathbf{5}$ Group A tensile test values

\begin{tabular}{|c|c|c|c|c|c|c|c|c|}
\hline \multirow[t]{2}{*}{ Subject } & \multicolumn{2}{|c|}{ Ultimate tensile load (N) } & \multicolumn{2}{|c|}{ Ultimate elongation (mm) } & \multicolumn{2}{|c|}{ Stiffness (N/meter) } & \multicolumn{2}{|l|}{ Failure mode } \\
\hline & $\begin{array}{l}\text { Experiment } \\
\text { knee }\end{array}$ & $\begin{array}{l}\text { Control } \\
\text { knee }\end{array}$ & $\begin{array}{l}\text { Experiment } \\
\text { knee }\end{array}$ & $\begin{array}{l}\text { Control } \\
\text { knee }\end{array}$ & $\begin{array}{l}\text { Experiment } \\
\text { knee }\end{array}$ & $\begin{array}{l}\text { Control } \\
\text { knee }\end{array}$ & Experiment knee & Control knee \\
\hline$\overline{A-1}$ & 466.719 & 607.656 & 10.629 & 8.258 & $43,909.963$ & $73,583.919$ & $\begin{array}{l}\text { Distal ligament } \\
\text { attachment }\end{array}$ & $\begin{array}{l}\text { Distal ligament } \\
\text { attachment }\end{array}$ \\
\hline$A-2$ & 645.625 & 745.625 & 9.6295 & 7.202 & $67,046.576$ & $103,530.27$ & Tibial avulsion & $\begin{array}{l}\text { Distal ligament } \\
\text { attachment }\end{array}$ \\
\hline$A-4$ & 649.688 & 627.344 & 11.622 & 12.363 & $51,901.566$ & $50,743.671$ & Femur metaphysis & Femur metaphysis \\
\hline$A-5$ & 312.031 & 273.438 & 5.521 & 5.841 & $56,517.116$ & $46,813.559$ & Tibial avulsion & Tibial avulsion \\
\hline
\end{tabular}

loadings as they presumed the central defect model to be mechanically stabile, although they did not tested it. In the current study, the sagittal stability of the central defect model was confirmed by measuring ATT. Our macroscopic assessments of the samples did not show any cartilage injury that could have occurred in the setting of instability, further supporting the stability of the central defect model.

The previous studies using the central defect model did not specifically discuss the treatment of the fat pad tissue while creating the ligament defect. Such tissue may be important, as demonstrated in some ACL circulation studies [34-36]. In the perfusion study of Dunlap et al., ACL perfusion clearly decreased with division of the fat pad [35]. Our histological assessments on selected knee samples showed that after 10 weeks, the central defect was fully healed in fat pad protected sample. In the fat pad excised sample, we observed pathological findings such as myxoid degeneration, edema, and fibrosis. Fat pad excision disturbed the healing. We believe the blood supply to the ACL was decreased by excision of the fat pad, leading to a poorer healing response. As expected, no differences in anterior tibial translation were noted in this stable knee model, but we did note significant higher stiffness in the fat pad excision group in tensile loadings, which is thought to be caused by the fibrotic changes in this group that were observed during histological assessment.

The findings of this study have several potential applications. First, when utilizing this model in a research setting, care should be taken not to harm the infrapatellar fat pad as damage to this structure can alter the healing process and affect structural properties of the ligament, potentially confounding study results. Second, in a clinical setting, one should consider the role of the fat pad in ACL healing and consider preservation of as much tissue as possible during ACL reconstruction. Some recently published studies also emphasize the altered biologic responses in the fat pad after ACL reconstruction that can also be associated with poor outcome. In the study of Solbak et al., inflammational and fibrotic changes are found in the fat pad after ACL reconstruction on a sheep model [39]. Wang et al. also found fibrotic changes which are correlated with magnetic resonance imaging after ACL transaction on a rat model [40]. These studies also give information about the close biologic connection of the ACL and fat pad like our study. Although beyond the scope of our work, future studies could further explore the role of the fat pad also in the ligamentization process.

A limitation of this study is that we evaluated histology in only one sample from each group. The findings of this study can be further evaluated with studies that include more samples for histological analyses and with biomechanical correlation.

\section{Conclusion}

The central defect type injury model was confirmed to be biomechanically stable in a goat model. Resection of the fat pad was noted to negatively affect defect healing and increase ligament stiffness in the central defect injury model.

Table 6 Group B tensile test values

\begin{tabular}{|c|c|c|c|c|c|c|c|c|}
\hline \multirow[t]{2}{*}{ Subject } & \multicolumn{2}{|c|}{ Ultimate tensile load $(\mathrm{N})$} & \multicolumn{2}{|c|}{ Ultimate elongation (mm) } & \multicolumn{2}{|c|}{ Stiffness (N/meter) } & \multicolumn{2}{|l|}{ Failure mode } \\
\hline & $\begin{array}{l}\text { Experiment } \\
\text { knee }\end{array}$ & $\begin{array}{l}\text { Control } \\
\text { knee }\end{array}$ & $\begin{array}{l}\text { Experiment } \\
\text { knee }\end{array}$ & $\begin{array}{l}\text { Control } \\
\text { knee }\end{array}$ & $\begin{array}{l}\text { Experiment } \\
\text { knee }\end{array}$ & $\begin{array}{l}\text { Control } \\
\text { knee }\end{array}$ & Experiment knee & Control knee \\
\hline B-2 & 465.313 & 500.938 & 5.379 & 7.535 & $86,505.484$ & $66,481.486$ & Tibial avulsion & Tibial avulsion \\
\hline B-3 & 790.625 & 717.813 & 8.079 & 8.802 & $97,861.74$ & $81,551.125$ & Tibial avulsion & Tibial avulsion \\
\hline B-4 & 525 & 580.469 & 8.355 & 5.235 & $62,836,625$ & $110,882.33$ & $\begin{array}{l}\text { Distal ligament } \\
\text { attachment }\end{array}$ & $\begin{array}{l}\text { Distal ligament } \\
\text { attachment }\end{array}$ \\
\hline B-5 & 418.438 & 527.344 & 5.634 & 6.608 & $74,270.146$ & $79,803.874$ & Tibial avulsion & Tibial avulsion \\
\hline
\end{tabular}




\section{Ethical approval}

The study was approved by the Ethic Commission of Ege University Animal Experiments Ethic Commission acceptance number 2010-134.

\section{Abbreviations}

ACL: anterior cruciate ligament; ATT: anterior tibial translation; MCL: medial collateral ligament; mm: millimeters; UTL: ultimate tensile load; UE: ultimate Elongation; N: Newton.

\section{Competing interests}

This study was funded in full by "Ege University Scientific Research Projects Coordination Unit", grant number 2012/TIP 010

\section{Authors' contributions}

ET and BK took part in every stages of the study including study design, operations, assessments, and publishing. BD performed the histopathological assessments. BU and SC took part in mechanical assessments. EKB took part in study design and writing. The corresponding author declares that all authors have read and approved the final submitted manuscript.

\section{Acknowledgements}

I would like to give my special thanks to Ege University research committee for their financial and laboratory support, Dokuz Eylul University biomechanical department for laboratory support, Veterinary Physician Ali Tuncay Erdogan for his help with animal care and anesthesia, and Professor Dr. EminTaskiran for study methodology advices.

\section{Author details}

${ }^{1}$ Orthopaedics and Traumatology Clinic, Bayburt State Hospital, Bayburt, Turkey. ${ }^{2}$ Orthopaedics and Traumatology Department, Ege University Hospital, Izmir, Turkey. ${ }^{3}$ Pathology Department, Ege University Hospital, Izmir, Turkey. ${ }^{4}$ Biomechanics Department, Dokuz Eylul University, Izmir, Turkey.

Received: 26 June 2015 Accepted: 25 August 2015

Published online: 04 September 2015

\section{References}

1. Murray MM. Current status and potential of primary ACL repair. Clin Sports Med. 2009;28:51-61.

2. Vavken $\mathrm{P}$, Murray MM. The potential for primary repair of the ACL. Sports Med Arthrosc. 2011;19:44-9.

3. Woo SL, Chan SS, Yamaji T. Biomechanics of knee ligament healing, repair and reconstruction. J Biomech. 1997;30:431-9.

4. Bray RC, Leonard CA, Salo PT. Vascular physiology and long-term healing of partial ligament tears. J Orthop Res. 2002;20:984-9.

5. Bray RC, Leonard CA, Salo PT. Correlation of healing capacity with vascular response in the anterior cruciate and medial collateral ligaments of the rabbit. J Orthop Res. 2003:21:1118-23.

6. Spindler KP, Murray MM, Devin C, Nanney LB, Davidson JM. The central ACL defect as a model for failure of intra-articular healing. J Orthop Res. 2006:24:401-6

7. Hefti FL, Kress A, Fasel J, Morscher EW. Healing of the transected anterior cruciate ligament in the rabbit. J Bone Joint Surg Am. 1991;73:373-83.

8. Kondo E, Yasuda K, Yamanaka M, Minami A, Tohyama H. Biomechanical evaluation of a newly devised model for the elongation-type anterior cruciate ligament injury with partial laceration and permanent elongation. Clin Biomech (Bristol, Avon). 2003;18:942-9.

9. Kondo E, Yasuda K, Yamanaka M, Minami A, Tohyama H. Effects of administration of exogenous growth factors on biomechanical properties of the

elongation-type anterior cruciate ligament injury with partial laceration. Am J Sports Med. 2005:33:188-96.

10. Murray MM, Spindler KP, Devin C, Snyder BS, Muller J, Takahashi M, et al. Use of a collagen-platelet rich plasma scaffold to stimulate healing of a central defect in the canine ACL. J Orthop Res. 2006;24:820-30.

11. Murray MM, Spindler KP, Ballard P, Welch TP, Zurakowski D, Nanney LB, et al. Enhanced histologic repair in a central wound in the anterior cruciate ligament with a collagen-platelet-rich plasma scaffold. J Orthop Res. 2007;25:1007-17.
12. O'Donoghue DH, Rockwood Jr CA, Frank GR, Jack SC, Kenyon R. Repair of the anterior cruciate ligament in dogs. J Bone Joint Surg Am. 1966;48:503-19.

13. Attia E, Brown H, Henshaw R, George S, Hannafin JA. Patterns of gene expression in a rabbit partial anterior cruciate ligament transection model: the potential role of mechanical forces. Am J Sports Med. 2010;38:348-56.

14. Ng GY, Oakes BW, McLean ID, Deacon OW, Lampard D. The long-term biomechanical and viscoelastic performance of repairing anterior cruciate ligament after hemitransection injury in a goat model. Am J Sports Med. 1996;24:109-17.

15. Wiig ME, Amiel $D$, Ivarsson $M$, Nagineni $C N$, Wallace CD, Arfors KE, et al. Type I procollagen gene expression in normal and early healing of the medial collateral and anterior cruciate ligaments in rabbits: an in situ hybridization study. J Orthop Res. 1991;9:374-82.

16. Killian ML, Isaac DI, Haut RC, Déjardin LM, Leetun D, Donahue $T L$, et al. Traumatic anterior cruciate ligament tear and its implications on meniscal degradation: a preliminary novel lapine osteoarthritis model. J Surg Res. 2010;164:234-41.

17. Proffen $B L, M c E l$ fresh $M$, Fleming BC, Murray MM. A comparative anatomical study of the human knee and six animal species. Knee. 2012;19:493-9.

18. Xerogeanes JW, Fox RJ, Takeda Y, Kim HS, Ishibashi Y, Carlin GJ, et al. A functional comparison of animal anterior cruciate ligament models to the human anterior cruciate ligament. Ann Biomed Eng. 1998;26:345-52.

19. Tischer T, Ronga M, Tsai A, Ingham SJ, Ekdahl M, Smolinski P, et al, Biomechanics of the goat three bundle anterior cruciate ligament. Knee Surg Sports Traumatol Arthrosc. 2009;17:935-40.

20. Abramowitch SD, Papageorgiou CD, Withrow JD, Gilbert TW, Woo SL. The effect of initial graft tension on the biomechanical properties of a healing ACL replacement graft: a study in goats. J Orthop Res. 2003;21:708-15.

21. Buma P, Kok HJ, Blankevoort L, Kuijpers W, Huiskes R, Van Kampen A. Augmentation in anterior cruciate ligament reconstruction-a histological and biomechanical study on goats. Int Orthop. 2004;28:91-6.

22. Cummings JF, Grood ES, Levy MS, Korvick DL, Wyatt R, Noyes FR. The effects of graft width and graft laxity on the outcome of caprine anterior cruciate ligament reconstruction. J Orthop Res. 2002;20:338-45.

23. Cummings JF, Grood ES. The progression of anterior translation after anterior cruciate ligament reconstruction in a caprine model. J Orthop Res. 2002;20:1003-8.

24. Drez Jr DJ, DeLee J, Holden JP, Arnoczky S, Noyes FR, Roberts TS. Anterior cruciate ligament reconstruction using bone-patellar tendon-bone allografts. A biological and biomechanical evaluation in goats. Am J Sports Med. 1991;19:256-63.

25. Fisher MB, Jung HJ, McMahon PJ, Woo SL. Suture augmentation following $A C L$ injury to restore the function of the $A C L, M C L$, and medial meniscus in the goat stifle joint. J Biomech. 2011;44:1530-5.

26. Fisher MB, Jung HJ, McMahon PJ, Woo SL. Evaluation of bone tunne placement for suture augmentation of an injured anterior cruciate ligament: effects on joint stability in a goat model. J Orthop Res. 2010;28:1373-9.

27. Fleming BC, Abate JA, Peura GD, Beynnon BD. The relationship between graft tensioning and the anterior-posterior laxity in the anterior cruciate ligament reconstructed goat knee. J Orthop Res. 2001;19:841-4.

28. Jackson DW, Grood ES, Arnoczky SP, Butler DL, Simon TM. Freeze dried anterior cruciate ligament allografts. Preliminary studies in a goat model. Am J Sports Med. 1987;15:295-303.

29. Jackson DW, Grood ES, Arnoczky SP, Butler DL, Simon TM. Cruciate reconstruction using freeze dried anterior cruciate ligament allograft and a ligament augmentation device (LAD). An experimental study in a goat model. Am J Sports Med. 1987;15:528-38.

30. Lundberg WR, Lewis JL, Smith JJ, Lindquist C, Meglitsch T, Lew WD, et al. In vivo forces during remodeling of a two-segment anterior cruciate ligament graft in a goat model. J Orthop Res. 1997;15:645-51.

31. Ng GY, Oakes BW, Deacon OW, McLean ID, Lampard D. Biomechanics of patellar tendon autograft for reconstruction of the anterior cruciate ligament in the goat: three-year study. J Orthop Res. 1995;13:602-8.

32. Powers DL, Jacob PA, Drews MJ. Anatomical reconstruction of the anterior cruciate ligament in goats. J Invest Surg. 1991;4:191-202.

33. Spindler KP, Murray MM, Carey $J L$, Zurakowski D, Fleming BC. The use of platelets to affect functional healing of an anterior cruciate ligament $(A C L)$ autograft in a caprine ACL reconstruction model. J Orthop Res. 2009;27:631-8.

34. Arnoczky SP, Rubin RM, Marshall JL. Microvasculature of the cruciate ligaments and its response to injury. An experimental study in dogs. J Bone Joint Surg Am. 1979;61:1221-9. 
35. Dunlap J, McCarthy JA, Joyce ME, Ogata K, Shively RA. Quantification of the perfusion of the anterior cruciate ligament and the effects of stress and injury to supporting structures. Am J Sports Med. 1989;17:808-10.

36. Toy BJ, Yeasting RA, Morse DE, McCann P. Arterial supply to the human anterior cruciate ligament. J Athl Train. 1995;30:149-52.

37. Zantop T, Ferretti M, Bell KM, Brucker PU, Gilbertson L, Fu FH. Effect of tunnel-graft length on the biomechanics of anterior cruciate ligamentreconstructed knees: intra-articular study in a goat model. Am J Sports Med. 2008;36:2158-66

38. Holden JP, Grood ES, Korvick DL, Cummings JF, Butler DL, Bylski-Austrow DI. In vivo forces in the anterior cruciate ligament: direct measurements during walking and trotting in a quadruped. J Biomech. 1994;27:517-26.

39. Solbak NM, Heard BJ, Achari Y, Chung M, Shrive NG, Frank CB, et al. Alterations in Hoffa's fat pad induced by an inflammatory response following idealized anterior cruciate ligament surgery. Inflamm Res. 2015;64(8):615-26.

40. Wang CY, Tsai PH, Siow TY, Lee HS, Chang YC, Hsu YC, et al. Change in T2* relaxation time of Hoffa fat pad correlates with histologic change in a rat anterior cruciate ligament transection model. J Orthop Res. 2015.Sep;33(9):1348-55

\section{Submit your next manuscript to BioMed Central and take full advantage of:}

- Convenient online submission

- Thorough peer review

- No space constraints or color figure charges

- Immediate publication on acceptance

- Inclusion in PubMed, CAS, Scopus and Google Scholar

- Research which is freely available for redistribution 